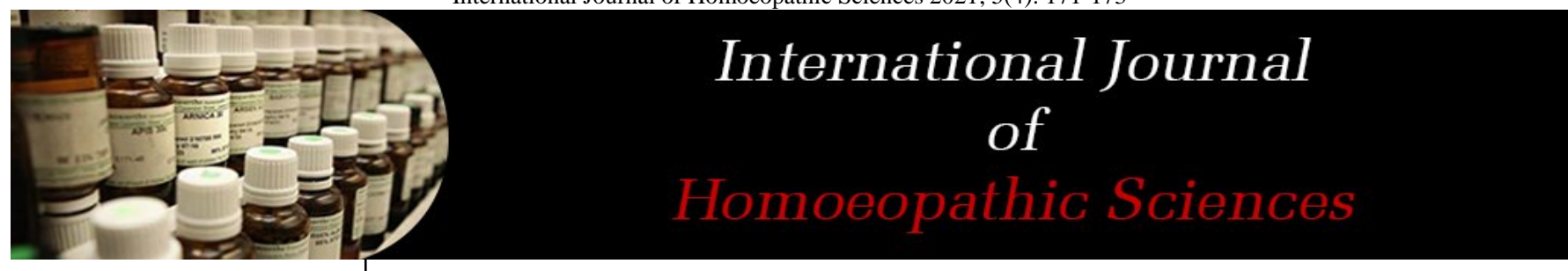

E-ISSN: $2616-4493$

P-ISSN: 2616-4485

www.homoeopathicjournal.com

IJHS 2021; 5(4): 171-173

Received: 22-07-2021

Accepted: 08-09-2021

Dr. Anita Bagga

Professor, Department of

Homoeopathic Pharmacy,

Homoeopathic Medical College

and Hospital, Sector-26.

Chandigarh, India

Dr. Amandeep Kaur Assistant Professor,

Department of Pathology and Microbiology, Homoeopathic Medical College and Hospital, Sector-26, Chandigarh, India

Corresponding Author:

Dr. Anita Bagga

Professor, Department of

Homoeopathic Pharmacy,

Homoeopathic Medical College

and Hospital, Sector-26,

Chandigarh, India

\section{Doctrine of signature and corona virus}

\section{Dr. Anita Bagga and Dr. Amandeep Kaur}

DOI: $\underline{\text { https://doi.org/10.33545/26164485.2021.v5.i4c.467 }}$

\section{Abstract}

The whole medical fraternity is going through a very challenging times in controlling the Covid-19 pandemic because of non-availability of specific medicine for treating corona virus infection.

Homoeopathic fraternity knows that there is a wide scope to offer treatment for corona virus. Dr. Hahenemann writes in Materia Medica pura under Drosera rotundifolia that "a single dose of drosera is quite sufficient in cure of epidemic whooping cough and he recommends further proving of its pure effects on the healthy human subjects. Sometimes things which looks very difficult has a simple solution led us to think of doctrine of signature.

From the doctrine of signature point of view, Drosera has resemblance with corona virus in many respects.

Keywords: Doctrine of signature, views, corona virus, homoeopathy, drosera rotundifolium, drug, drug proving, relation

\section{Introduction}

Doctrine of signature is a relation between source of drug and symptoms produced by the same drug after drug proving.

The doctrine of signature is an ancient philosophy which postulates that the parts of plant that bear resemblance with the parts of human body or animals has useful relevance to them. It can also refer to the environment or places where the plants grow. Originally relating to herbs and medicinal plants, the modern day application of this doctrine says that many plants shows the same resemblance with our body parts or their physiological functions. Even Dioscorides and Galen endorsed this fact.

History: Doctrine of signature was developed by Swiss physician "Paracelsus". He wrote "Nature marks each growth according to its curative benefit". Doctrine of signature signals, such as shape, colour and texture, serve as hints pointing to which organ a plant treats.

When medicinal science was developing at end of the sixteenth century, the role of medicine was largely developed on resemblance and then it largely guided the medical texts. Modern nutritionist already has recognised the fact that walnuts has resemblance with the brain and they are good for functioning of the brain. Similarly, shape of an almond resembles eye so they are good for eyesight.

Examples used in homoeopathy related to doctrine of signature are as follows

- In clinical practice, Belladonna is an acute of calcarea carbonicum. Hence, complimentary relationship exists between the two. The same complimentary relationship is seen in the climatic conditions as Belladonna grows best in Calcium rich soil.

- Bryonia Alba produces a very bitter taste in mouth during drug proving. The tongue gets coated yellow-white with acrid discharges and the same is seen in the character of roots from which part Bryonia is prepared. Bryonia roots are flabby, yellowish - white and bitter in taste.

- Jaundice, a clinical condition produces yellow discolouration of skin and Medicine Gelsemium acts well in jaundice which bears flowers, yellow in colour.

- Lachesis mutus is useful for all those symptoms where there is intolerance of tight clothing especially around neck, blue discolouration of the skin and tongue and trembling of tongue when protuded. Snake lachesis is also very sensitive for any kind of 
constriction marked especially in its neck region. Persons after snake poisoning develops blue discolouration due to hemorrhagic disintegration.

- Medicine Tarentula Hispania is prepared from Spanish spider. The spider is collected by the process of hunting by beating drums vigorously as spider is very sensitive to noise. When drums are beaten, it comes out of his hiding place and is catched. Same sensitivity towards music is exhibited in patients of Tarentula after drug proving.

- Pulsatilla- It is known for its changeability and the flowers of pulsatilla are so delicate that even a little draft of air makes them to change their position. The peculiar symptom of pulsatilla is thirstlessness along with dryness of mouth. And it's worth mentioning that Pulsatilla plant grows in deserts.

- Euphrasia- It is a famous medicine for treating any complaint when concomitant symptom of lachrymation from eyes develop and the resemblance of eye is seen in the plant itself because plant has a black spot in corolla resembling pupil of an eye.
Many stalwarts like Dr. C Hering, Dr. C.M. Boger, Dr H.A.Roberts and Dr. J.C.Burnett had supporting attitude towards this doctrine. In the introduction of the remedy Magnesia Carbonica, Dr.J.H. Clarke wrote that it is often found that the physical characteristics of the substances correspond with their dynamic influences. The second reference supporting the doctrine of signature in the Clark's Materia Medica will be found in the introduction of Magnesia Phosphorica, where he mentioned that there are other means besides proving of finding the keynote symptoms of remedies.

\section{Discussion \\ Nature is complete and in abundance with all the resources and means that can guide us the way to eradicate all diseases. If there is a disease, then there must be present a source to suggest its cure too. Doctrine of signature suggested us the role of Drosera as a medicine for covid-19. There exists a strong relation between corona virus and drosera not only in structure but in its pathogenesis, symptoms after drug proving.}

\section{Doctrine of signature between coronavirus and drosera rotundifolia}

Table 1: Drosera rotundifolia

\begin{tabular}{|c|c|c|}
\hline & Coronavirus & Drosera rotundifolia (Sundew) \\
\hline \multicolumn{3}{|l|}{ Structure } \\
\hline Features & $\begin{array}{l}\text { It's an off-white spherical in shape. The protein } \\
\text { particles look yellow and some spikes like structure } \\
\text { emerge from surface which is red in colour looking } \\
\text { like a crown. Hence, called corona. }\end{array}$ & $\begin{array}{l}\text { The upper surface of the lamina is covered and is studied with } \\
\text { glandular hairs which are red in colour and secrete mucus which is } \\
\text { very sticky. It is loaded with sugary substance that further causes } \\
\text { adherence of its prey. }\end{array}$ \\
\hline Action & Coronavirus chiefly affects Respiratory system. & Its sphere of action is marked on the Respiratory system. \\
\hline $\begin{array}{c}\text { Relation with } \\
\text { Animals }\end{array}$ & It has a relation with bats. & $\begin{array}{l}\text { It digests insects; } \\
\text { Sheep, after eating Drosera, develop a very violent cough that proves } \\
\text { fatal for them. }\end{array}$ \\
\hline \begin{tabular}{c|} 
Type of \\
cough / \\
Symptoms \\
Pathogenesis
\end{tabular} & $\begin{array}{l}\text { It produces dry cough which persist and along with } \\
\text { it, patient suffers from shortness of breath and } \\
\text { muscular pains. } \\
\text { It is the adhering capacity of corona virus that helps } \\
\text { in its pathogenesis. }\end{array}$ & $\begin{array}{c}\text { Sensation of roughness and dryness in throat with inclination to } \\
\text { cough; } \\
\text { Spasmodic cough resembling whooping cough; } \\
\text { Dry spasmodic cough with retching; } \\
\text { Oppressed breathing when talking; } \\
\text { Cough is excited by laughter, weeping and mental emotions; } \\
\text { Aggravation after lying down and still more increased after midnight. } \\
\text { Drosera catches its prey after adhering to its prey. }\end{array}$ \\
\hline
\end{tabular}

\section{Symptoms of covid 19 according to WHO Most common symptoms}

Fever.

Dry cough.

Tiredness.

\section{Less common symptoms}

Aches and pains.

Sore throat.

Diarrhoea.
Conjunctivitis.

Headache.

Loss of taste or smell.

A rash on skin, or discolouration of fingers or toes.

\section{Serious symptoms}

Difficulty breathing or shortness of breath.

Chest pain or pressure.

Loss of speech or movement. 


\section{Drosera has similar symptoms after its drug proving}

Food is quite without any taste for him. Dyspnoea, cough coming quite deep down in the chest. When coughing and breathing, stitches in the pectoral muscles. Fever; confused heavy head, constant chilliness.

All limbs are as if bruised and are also painful externally. A pain compounded of gnawing and shooting in the shafts of the bones of the arms, thighs, and legs, particularly severe in the joints, with severe stitches in the joints, less felt when moving than when at rest.

Drosera has an evil reputation in regard to sheep fed on pastures where it abounds. They are said to acquire a very violent cough and to waste away as written by Dr. Margeret Taylor under Drosera rotundifolia in her textbook of Homoeopathic drug pictures of material Medica.

\section{Conclusion}

The disease caused by corona virus is not only fatal but those recovering from it mostly remains under its adverse effects for lifetime.

Dr. Margaret Tyler quotes in Drosera medicine, "Where drosera helps, results are very soon seen and invariably in renewed health and spirits and in utterly changed appearance. The patient who needs drosera and gets it, simply blooms. There is no other word for it. "

Dose: Margeret Taylor writes under Drosera that "Dr Hahnemann states that a single dose of 30th potency is quite sufficient for the cure of epidemic whooping cough". The cure takes place, he says, with certainty in from 7-9 days under non medicinal diet. Care should be taken not to give 2nd dose immediately after 1st dose, for that would not only prevent the good result but do serious injury, as I know from experience.

If this medicine is further explored in context to corona virus, may be a whole new way to the treatment of Covid-19 infection comes into picture.

\section{References}

1. Ulmar Grafe T, Caroline Schöner R, Gerald Kerth, Anissa Junaidi, Michael Schöner G, 2011.

2. Wikipedia

3. Page. No.570, Materia medica pura, volume1.

4. Clarke Materia Medica

5. https://www.healthyhildegard.com/doctrine-signatureshealing-plants/

6. http://www.homeopathycenter.org/remedy/sarracenia https://www.homeobook.com/doctrine-of-signature-asource-of-homoeopathic-materia-medica/

7. https://en.m.wikipedia.org/wiki/Doctrine_of_signatures

8. https://www.who.int/healthtopics/coronavirus\#tab=tab_3

9. Pg.no.353, 354, 357,Homoeopathic drug pictures by Dr ML Tyler, Reprint edition, 1995

10. Pg. No. 574,576,577,579, 580 Materia Medica Pura, vol.1, IBPS.

11. The Order of Things, p. 17

12. https://www.slideshare.net/jasleenluthra79/pulsatillanigricans-2-54551693

13. http://homoeoplus.com/euphrasia-a-homoeopathymedicine-for-eye-aliments/

14. Homoeopathic drug pictures by Margeret Taylor, page no. 354. 